\title{
Severity and Cost of Unsafe Abortion Complications Treated in Nigerian Hospitals
}

\author{
By Stanley K. \\ Henshaw, Isaac \\ Adewole, Susheela \\ Singh, Akinrinola \\ Bankole, Boniface \\ Oye-Adeniran and \\ Rubina Hussain \\ Stanley K. Henshaw \\ is senior fellow, \\ Susheela Singh is vice \\ president for research, \\ Akinrinola Bankole is \\ director of interna- \\ tional research and \\ Rubina Hussain is \\ research associate, all \\ with the Guttmacher \\ Institute, New York. \\ Isaac F. Adewole is \\ obstetrician and \\ gynecologist, College \\ of Medicine, Universi- \\ ty of Ibadan, Nigeria, \\ and Boniface \\ Oye-Adeniran is \\ obstetrician and \\ gynecologist, College \\ of Medicine, Universi- \\ ty of Lagos, Nigeria.
}

CONTEXT: Each year, thousands of Nigerian women have unintended pregnancies that end in illegal abortion. Many such procedures occur under unsafe conditions, contributing to maternal morbidity and mortality.

METHODS: In a 2002-2003 survey of women and their providers in 33 hospitals in eight states across Nigeria, 2,093 patients were identified as being treated for complications of abortion or miscarriage or seeking an abortion. Women's abortion experiences and the health consequences and associated costs were examined through bivariate analysis. Multivariate analysis was used to examine the characteristics of women by type of pregnancy loss and to compare characteristics among three groups of women who had induced abortions in differing circumstances.

RESULTS: Among women admitted for abortion-related reasons, 36\% had attempted to end the pregnancy before coming to the hospital (including $24 \%$ with and $12 \%$ without serious complications), $33 \%$ obtained an induced abortion at the facility (not withstanding the country's restrictive law) without having made a prior abortion attempt and $32 \%$ were treated for complications from a miscarriage. Of women with serious complications, $24 \%$ had sepsis, $21 \%$ pelvic infection and $11 \%$ instrumental injury; $22 \%$ required blood transfusion and $10 \%$ needed abdominal surgery. The women in this group were poorer and later in gestation than those who sought abortions directly from hospitals. They paid more for treatment (about 13,900 naira) than those who went directly to the hospital for an abortion (3,800 naira) or those treated for miscarriage (5,100 naira).

CONCLUSIONS: Policy and program interventions are needed to improve access to contraceptive services and postabortion care in order to reduce abortion-related morbidity and mortality. International Family Planning Perspectives, 2008, 34(1):40-50

Abortion is legally restricted in most African countries, and in Nigeria it is permitted only to save the life of a pregnant woman. Nevertheless, the practice is common: According to an estimate based on a 1996 national survey of physicians and hospitals in Nigeria, 610,000 abortions occurred in a one-year period, a rate of about 25 abortions per 1,000 women of childbearing age (15-44 years). ${ }^{1}$ This study also found that $27 \%$ of physicians in private practice performed abortions despite the legal restrictions.

A majority of the abortions in Nigeria take place under unsafe conditions and constitute a major source of maternal morbidity and mortality. A study based on the 1996 survey of physicians and hospitals estimated that 142,000 women were treated for complications of abortion each year, and experts believe that unsafe abortion accounts for at least $13 \%$ and possibly $30-40 \%$ of maternal deaths. ${ }^{1-3}$ However, a substantial proportion of women having an abortion in Nigeria seek the procedure from a physician, often in a private clinic or hospital. Research in the mid-1990s, based on a nationally representative sample of facilities, estimated that $27 \%$ of women receiving abortion care were seeking an abortion, $47 \%$ needed treatment for complications of an abortion attempt and 26\% were treated for complications of a spontaneous abortion. ${ }^{1}$ The present study provides new and comprehensive information from personal interviews of women with all types of pregnancy loss, and also obtains medical information from their providers.

Unsafe abortion is not only a significant cause of morbidity and mortality among women, but also an economic drain on the health care system. As in many other countries in the region, a high proportion of gynecological admissions to hospitals result from complications of unsafe induced abortion. Providing postabortion care to these women involves huge costs and thus diminishes the health care system's capacity to provide other needed services. ${ }^{4}$ Reducing the burden of unsafe abortion on women, their families, health care providers and the fragile health care system presents an important policy challenge to Nigeria and similar developing countries.

At the same time, some evidence suggests that abortions may be safer in Nigeria now than they were a decade ago, as more women appear to be obtaining the procedure from trained professionals. According to data from a survey of women in 2002-2003, an estimated 10\% of women who had abortions were hospitalized due to complications. ${ }^{5}$ In 1996 , this proportion was estimated at $20 \%$ on the basis of health professionals' perceptions. ${ }^{6}$ Although the methodologies that produced these estimates are different, the substantial reduction suggests that abortion may have become safer. 
Indirect evidence from the 1990 and 2003 Nigeria Demographic and Health Surveys (NDHS) suggests that the number of abortions taking place in the country has not declined, and may be rising. For example, $52 \%$ of married women desired to delay or stop childbearing in 2003, compared with 48\% in 1990; in addition, 14\% of all births in the five years preceding the 2003 NDHS were mistimed or unwanted, compared with $10 \%$ of births in the five years prior to the 1990 DHS.,8 The proportion of women aged 20-24 who had had premarital sex before age 20, and therefore were likely to have been at risk of unwanted pregnancy during their adolescent years, increased from 27\% in 1990 to $32 \%$ in $2003.9,10$ Contraceptive use remains low: Only 13\% of currently married women aged 15-49 were using any method in 2003, including 8\% who were using a modern method. Among unmarried, sexually active young women aged 15-24, a group at high risk of unintended pregnancy and abortion, the proportion using any method rose from $40 \%$ in 1990 to $51 \%$ in $2003 .{ }^{11}$ Thirtytwo percent of married women and $54 \%$ of unmarried, sexually active women in 2003 wanted to prevent or delay pregnancy, but were not using an effective method. ${ }^{12}$

We provide new information on the health consequences of unsafe abortion, a subject that is difficult to research in contexts where abortion is severely restricted by law. Updated information is necessary for health planners and providers seeking to assess the costs of unsafe abortion to women and to the health care system, given the high likelihood that the conditions of abortion provision and demand for abortion have changed over the past decade. This study, based on a 2002-2003 survey, highlights potential benefits to women's health and survival that could be gained by reducing the consequences of unsafe abortion and improving women's and couples' ability to prevent unintended pregnancy.

The article addresses differences in abortion morbidity among key population groups, within the constraints of sample size. This is a necessity, given the large social, cultural and economic differences that exist within Nigeria; in addition, these variations are likely to have strong relationships to sexual and reproductive values, preferences and behaviors, and to access to information and services. The South, which is predominantly Christian, is the more urbanized, educated and economically advanced part of the country, while the North is more conservative, rural, less educated, poorer and largely Muslim.

To better understand morbidity resulting from unsafe abortion and to better assess its current magnitude and characteristics, we undertook research to examine and document the characteristics of women who are admitted to hospitals for complications from unsafe abortion (or to obtain an induced abortion), the conditions under which women obtain abortions (e.g., where they go, whom they see, what method is used, at what gestation and what cost), the nature and severity of complications resulting from unsafe abortions, the type of treatment used for abortion complications and the cost of treatment.

\section{METHODOLOGY}

\section{Data}

The Guttmacher Institute and its Nigerian partner organization, the Campaign Against Unwanted Pregnancy, carried out a survey of women admitted to public and private medical facilities for treatment of complications of induced or spontaneous abortion or to obtain an abortion. The survey was conducted between September 2002 and July 2003 in 33 hospitals located in eight states in Nigeria (Ekiti, Gombe, Kaduna, Kano, Kogi, Lagos, Imo and Rivers). These states comprise the most urban state and the most rural state from each of the country's four health zones (Northeast, Northwest, Southeast and Southwest), according to data on the rural-urban distribution of women from the National Population Commission. In addition, at least one state came from each of the current six geopolitical zones (North East, North West, North Central, South East, South West and South South).

A mix of facilities was selected to represent all of the major types of facilities that treat postabortion patients. In each of the eight sampled states, two public and two private hospitals (including missionary hospitals) were selected; tertiary and secondary hospitals were part of the mix. An additional hospital was selected in Kogi State because the required number of interviews in one of the private facilities could not be completed due to the proprietor's lack of cooperation. The total sample of hospitals consisted of seven public tertiary (teaching) hospitals, 10 public secondary hospitals, 14 private hospitals and two mission hospitals. The sampled hospitals were purposively selected to have a large caseload of patients seeking abortion-related treatment to assure an adequate number of interviews within a manageable and affordable period of fieldwork. Most of the hospitals were located in urban areas, as hospitals in Nigeria generally are.

All women who were admitted for treatment of pregnancy loss during the study period were included in the sample, as well as those who came to the facility to request an abortion. Women reporting spontaneous abortions were included because it is not always easy to distinguish such events from induced abortions, and because inclusion of all patients being treated for pregnancy loss provides a group of women who can be compared with those who are considered to have had induced abortions. The health care provider for each surveyed woman was interviewed to provide matched physician data for each respondent. In most of the cases, the individual interviewed was the attending physician or an associate, for example, the attending nurse.

The survey was conducted using structured questionnaires in face-to-face interviews. The questionnaires were pretested at a tertiary hospital and a private hospital in Ibadan, Oyo State. The interviewer obtained social and demographic characteristics of women and their partners, and women's contraceptive and pregnancy histories, with a particular focus on unwanted pregnancy and abortion. Questions on abortion elicited information on issues such as the abortion decision-making process, reasons why 
women obtained abortions, the abortion-seeking process (including how many separate steps were taken prior to coming to the facility, and some information on each step), the conditions under which the women attempted to end their current pregnancy, complications associated with the abortion attempt and costs of treatment.

An abortion was considered induced rather than spontaneous if the patient had made an abortion attempt prior to coming to the facility or if she had come to the hospital seeking an abortion. Patients were also considered to have attempted to end their pregnancy if they reported that they had done so or if the physician indicated that either the patient or someone else had said that such an attempt had been made. Other cases were classified according to the physician's diagnosis.

Women who reported that they had attempted to end their pregnancy before coming to the hospital were asked a number of questions about their abortion attempts: whom they saw or what they did at their first step, where they saw the person or obtained the materials used, what the person did, how much it cost and what, if any, health problems resulted. These same questions were asked about each additional step they took to end the pregnancy, up to a maximum of four steps. Women were also asked about the out-of-pocket cost of treatments they obtained before they came to the hospital.

Each patient's medical provider was asked about specific details of medical care and surgical procedures provided at the hospital, the total hospital charge to the woman and three types of additional expenses (additional payments to the doctor, supplies used in the hospital and medications). These charges likely do not reflect the full cost of care, particularly within public sector or charitable facilities (government-owned and missionary hospitals), where women are not generally charged the full cost of their care.

To preserve the respondents' privacy, names of interviewees were not recorded on questionnaires or in any documents for this study. The Guttmacher Institute's Internal Review Board approved the study design, fielding procedures and questionnaires. In addition, an ethical re- view panel consisting of five members from the College of Medicine, University of Lagos, and Lagos University Teaching Hospital reviewed the study design and protocols to ensure that confidentiality and ethical issues were adequately addressed.

Medical doctors and nurses were chosen to be interviewers and supervisors because past experience has shown that they are successful in interviewing both patients and providers on this issue, and also because their expertise facilitated data collection for parts of the interview that concerned clinical aspects of medical care and involved extracting information from patients' medical records.

The survey included interviews with 2,330 women and one key provider per patient in the 33 hospitals. Of the women interviewed, 2,093 were eligible for analysis. The 237 cases that were omitted from the analysis included 112 women with ectopic pregnancies, 71 who were seeking pregnancy termination and were refused or referred elsewhere, 36 who were treated for pregnancy complications other than pregnancy loss, 15 whose physician was not interviewed and three women who were not pregnant.

\section{Limitations}

The study has some limitations that should be taken into account. We may have missed some women who were admitted to the hospital for abortion-related reasons during the time of the survey. This may be particularly true for women who were either treated as outpatients and were admitted when the interviewers were not in the hospital or women who were too sick to be interviewed although the interviewer was available. However, we do not expect that the number of such women is large enough to have an impact on the representativeness of our sample.

Of the women who were classified as having attempted to end their pregnancies, $92 \%$ reported having done so to the interviewer. This, together with the high ratio of induced to spontaneous abortions, suggests that women were fairly open about reporting their abortion attempts. It is nevertheless possible that some induced abortions could have been misclassified, given that some women

\begin{tabular}{|c|c|c|c|c|c|c|c|}
\hline \multirow[t]{2}{*}{ Type and reason } & \multirow{2}{*}{$\begin{array}{l}\text { Total } \\
(\mathrm{N}=2,093)\end{array}$} & \multicolumn{2}{|l|}{ Region‡ } & \multicolumn{4}{|l|}{ Hospital§ } \\
\hline & & $\begin{array}{l}\text { South } \\
(\mathrm{N}=1,116)\end{array}$ & $\begin{array}{l}\text { North } \\
(\mathrm{N}=965)\end{array}$ & $\begin{array}{l}\text { Tertiary } \\
(\mathrm{N}=315)\end{array}$ & $\begin{array}{l}\text { Secondary } \\
(\mathrm{N}=668)\end{array}$ & $\begin{array}{l}\text { Private } \\
(\mathrm{N}=976)\end{array}$ & $\begin{array}{l}\text { Mission } \\
(\mathrm{N}=128)\end{array}$ \\
\hline Abortion attempted outside hospital & 35.6 & 38.2 & $32.6 * *$ & 26.7 & 36.2 & 32.3 & $79.7^{* *}$ \\
\hline Presented with serious complications, treated in hospital & 23.5 & 22.2 & $25.0^{* *}$ & 25.7 & 26.2 & 13.4 & $79.7^{* *}$ \\
\hline Presented without serious complications, induced in hospital & 12.1 & 16.0 & $7.6^{* *}$ & 1.0 & 10.0 & 18.9 & $0.0^{* *}$ \\
\hline No prior attempt, abortion induced in hospital & 32.6 & 43.3 & $20.0 * *$ & 2.2 & 23.5 & 52.4 & $3.1^{* *}$ \\
\hline $\begin{array}{l}\text { Spontaneous abortion, with complications } \\
\text { treated in hospital (ref) }\end{array}$ & 31.8 & 18.5 & 47.5 & 71.1 & 40.3 & 15.4 & 17.3 \\
\hline Total & 100.0 & 100.0 & 100.0 & 100.0 & 100.0 & 100.0 & 100.0 \\
\hline
\end{tabular}


may have been reluctant to report an abortion attempt and symptoms may not have clearly indicated that an attempt to terminate the pregnancy had been made.

\section{Analysis}

We used chi-square tests to compare the social and demographic characteristics of women who had attempted or had an induced abortion (in or outside the hospital) with women who had been admitted because of a miscarriage. The characteristics examined included age, marital status, religion, residence, education level, wealth and parity. In addition, we compared pregnancy outcomes for women in different categories of gestation at admission to the hospital and according to whether or not the patient had had a previous induced abortion.

To understand what women had done to end a pregnancy before they arrived at a hospital, we examined the type of providers from whom women had sought an abortion, the methods used to induce an abortion and the complications resulting from attempts to end a pregnancy. We compared differences in cost and method of abortion by provider as well as type of complications from the abortion attempts by method.

We also examined the differences in the diagnoses at discharge between women classified as having experienced a spontaneous abortion and those who had had an induced abortion. The types of medical treatment women received during their hospitalization and the costs to women and their family associated with these treatments were analyzed. In addition, the cost of each abortion procedure or treatment that a woman received before she came to the hospital was obtained and these costs were combined to produce the total cost incurred.

Most of the analyses were done via cross-tabulations, and chi-square tests were used to identify associations between variables. However, to compare the correlates of induced and spontaneous abortions, we used logistic regression. Similarly, among women who had an induced abortion, we used logistic regression to explore the factors associated with whether a woman went straight to the hospital for an abortion or was admitted to the facility following an abortion attempt.

\section{RESULTS}

\section{Types of Abortion Patients Treated in Hospitals}

On the basis of information from women and medical providers, the 2,093 respondents were classified into four groups (Table 1): two groups of women who had attempted to end their pregnancy before coming to the hospital (36\%)-those who were admitted to the hospital with serious complications (24\%) and those who had no serious complications but were still pregnant and obtained an abortion at the hospital (12\%); women who obtained an induced abortion at the facility (despite Nigeria's restrictive law) without having made any prior abortion attempt (33\%) and women who had complications from a spontaneous abortion (32\%).
TABLE 2. Percentage distribution of women admitted to hospital for treatment related to pregnancy loss, by selected characteristics, according to reason for admission

\begin{tabular}{|c|c|c|c|c|c|}
\hline \multirow[t]{2}{*}{ Characteristic } & \multirow{2}{*}{$\begin{array}{l}\text { Spontaneous } \\
(\mathrm{N}=666)\end{array}$} & \multirow{2}{*}{$\begin{array}{l}\text { Induced } \\
\text { abortion } \\
(\mathrm{N}=1,427)\end{array}$} & \multicolumn{3}{|c|}{ Type of induced abortion } \\
\hline & & & $\begin{array}{l}\text { No prior } \\
\text { attempt, } \\
\text { induced } \\
\text { in hospital } \\
(\mathrm{N}=682)\end{array}$ & $\begin{array}{l}\text { Attempted } \\
\text { outside, } \\
\text { no serious } \\
\text { presenting } \\
\text { complications, } \\
\text { induced in } \\
\text { hospital } \\
(\mathrm{N}=254)\end{array}$ & $\begin{array}{l}\text { Obtained } \\
\text { outside, } \\
\text { serious } \\
\text { presenting } \\
\text { complications } \\
\text { treated in } \\
\text { hospital } \\
(\mathrm{N}=491)\end{array}$ \\
\hline \multicolumn{6}{|l|}{ Age } \\
\hline$<20$ (ref) & 10.0 & 21.6 & 20.4 & 20.3 & 23.9 \\
\hline $20-24$ & 20.9 & 37.8 & 40.5 & 45.4 & $30.1^{* *}$ \\
\hline $25-29$ & 26.7 & $19.6^{* *}$ & 18.2 & 18.3 & 22.2 \\
\hline$\geq 30$ & 42.5 & $21.0^{* *}$ & 20.9 & 15.9 & 23.9 \\
\hline \multicolumn{6}{|l|}{ Marital status } \\
\hline Never-married (ref) & 2.6 & 60.1 & 60.7 & 67.1 & 55.7 \\
\hline Married & 97.0 & $35.0^{* *}$ & 35.2 & 29.7 & $37.3^{*}$ \\
\hline Formerly married & 0.5 & 4.9 & 4.0 & 3.2 & $7.0^{*}$ \\
\hline \multicolumn{6}{|l|}{ Religion } \\
\hline Muslim (ref) & 59.9 & 22.2 & 19.5 & 16.6 & 28.9 \\
\hline Catholic & 12.6 & $27.2^{* *}$ & 29.7 & 35.6 & $19.4^{* *}$ \\
\hline Protestant & 11.4 & $32.5^{* *}$ & 35.5 & 28.5 & $30.4^{* *}$ \\
\hline Other Christian & 13.5 & $17.3^{* *}$ & 15.0 & 19.4 & $19.4 \dagger$ \\
\hline Other/none & 2.6 & 0.8 & 0.3 & 0.0 & $1.9^{*}$ \\
\hline \multicolumn{6}{|l|}{ Residence } \\
\hline Town or city (ref) & 86.9 & 79.2 & 81.2 & 71.8 & 80.3 \\
\hline Village & 13.1 & $20.8^{* *}$ & 18.8 & 28.3 & $19.7^{* *}$ \\
\hline \multicolumn{6}{|l|}{ Education } \\
\hline No schooling (ref) & 18.4 & 5.5 & 4.7 & 4.3 & 7.3 \\
\hline Primary $¥$ & 19.3 & $10.7^{* *}$ & 7.7 & 9.9 & 15.4 \\
\hline Secondarył & 36.0 & $48.1^{* *}$ & 45.8 & 51.7 & 49.3 \\
\hline Postsecondary & 24.1 & $34.7^{* *}$ & 41.1 & 33.2 & $26.8^{* *}$ \\
\hline Other & 2.3 & 0.9 & 0.8 & 0.8 & 1.2 \\
\hline \multicolumn{6}{|l|}{ Standard of living } \\
\hline Poor (ref) & 37.8 & 31.5 & 23.3 & 37.0 & 39.9 \\
\hline Middle & 31.4 & $33.6^{*}$ & 32.7 & 33.9 & $34.6^{* *}$ \\
\hline Rich & 30.8 & $35.0^{* *}$ & 44.0 & 29.1 & $25.5^{* *}$ \\
\hline \multicolumn{6}{|c|}{ No. of living children } \\
\hline 0 (ref) & 30.0 & 65.1 & 66.7 & 70.1 & 60.3 \\
\hline $1-3$ & 45.6 & $20.7^{* *}$ & 18.8 & 18.1 & $24.6^{*}$ \\
\hline$\geq 4$ & 24.3 & $14.2^{* *}$ & 14.5 & 11.8 & 15.1 \\
\hline \multicolumn{6}{|c|}{ No. of prior induced abortions } \\
\hline 0 (ref) & 91.3 & 61.9 & 60.7 & 73.2 & 57.6 \\
\hline 1 & 4.1 & $15.4^{* *}$ & 12.3 & 13.4 & $20.8^{* *}$ \\
\hline$\geq 2$ & 4.7 & $22.7^{* *}$ & 27.0 & 13.4 & $21.6^{* *}$ \\
\hline \multicolumn{6}{|l|}{ Wks. of gestation } \\
\hline$<8$ (ref) & 9.0 & 47.1 & 64.5 & 46.8 & 22.9 \\
\hline $8-12$ & 62.1 & $41.6^{* *}$ & 32.3 & 43.7 & $53.4^{* *}$ \\
\hline $13-19$ & 20.9 & $7.5^{* *}$ & 1.6 & 5.6 & $16.6^{* *}$ \\
\hline$\geq 20$ & 8.0 & $3.9^{* *}$ & 1.4 & 4.0 & $7.1^{* *}$ \\
\hline Total & 100.0 & 100.0 & 100.0 & 100.0 & 100.0 \\
\hline
\end{tabular}

Distinct differences are apparent across population subgroups in whether women had come to facilities for a termination or for treatment of complications resulting from an unsafe induced abortion or a spontaneous abortion. In the South, $43 \%$ of the women admitted sought a termina- 
TABLE 3. Odds ratios from logistic regression analysis to identify associations between social and demographic characteristics and having an induced abortion or attempting an abortion outside the hospital

\begin{tabular}{|c|c|c|c|}
\hline Characteristic & $\begin{array}{l}\text { Induced } \\
\text { vs. } \\
\text { spontaneous } \\
\text { abortion }\end{array}$ & $\begin{array}{l}\text { Abortion in- } \\
\text { duced inside } \\
\text { after outside } \\
\text { attempt with } \\
\text { no serious } \\
\text { presenting } \\
\text { complications } \\
\text { vs. induced } \\
\text { inside, no } \\
\text { outside } \\
\text { attempt }\end{array}$ & $\begin{array}{l}\text { Abortion } \\
\text { obtained } \\
\text { outside with } \\
\text { serious pre- } \\
\text { senting com- } \\
\text { plications vs. } \\
\text { induced inside, } \\
\text { no outside } \\
\text { attempt }\end{array}$ \\
\hline \multicolumn{4}{|l|}{ Age } \\
\hline$<20$ (ref) & 1.00 & 1.00 & 1.00 \\
\hline $20-24$ & 0.87 & $1.60^{*}$ & 0.96 \\
\hline $25-29$ & $0.33^{* *}$ & $1.63 \dagger$ & $1.63^{*}$ \\
\hline$\geq 30$ & $0.27^{* *}$ & 1.32 & $1.71 \dagger$ \\
\hline \multicolumn{4}{|l|}{ Marital status } \\
\hline Married (ref) & 1.00 & 1.00 & 1.00 \\
\hline $\begin{array}{l}\text { Not currently } \\
\text { married }\end{array}$ & $76.61^{* *}$ & 1.16 & 1.20 \\
\hline \multicolumn{4}{|l|}{ Religion } \\
\hline Muslim (ref) & 1.00 & 1.00 & 1.00 \\
\hline Catholic & $1.58 \dagger$ & $1.66+$ & 0.97 \\
\hline Protestant & $3.33^{* *}$ & 1.18 & 1.05 \\
\hline Other Christian & $1.83^{*}$ & $1.91^{*}$ & 1.45 \\
\hline \multicolumn{4}{|l|}{ Residence } \\
\hline Town or city (ref) & 1.00 & 1.00 & 1.00 \\
\hline Village & $2.08^{* *}$ & 1.21 & $0.70 \dagger$ \\
\hline \multicolumn{4}{|l|}{ Region } \\
\hline South (ref) & 1.00 & 1.00 & 1.00 \\
\hline North & $0.51^{* *}$ & 1.06 & $1.70^{* *}$ \\
\hline \multicolumn{4}{|l|}{ Education } \\
\hline \multicolumn{4}{|l|}{ No schooling/ } \\
\hline Primarył & 0.97 & 2.00 & $2.59^{* *}$ \\
\hline Secondary $\neq$ & 1.06 & 1.63 & 1.63 \\
\hline Postsecondary & 1.01 & 1.42 & 1.49 \\
\hline \multicolumn{4}{|c|}{ Standard of living } \\
\hline Poor (ref) & 1.00 & 1.00 & 1.00 \\
\hline Nonpoor & 1.18 & $0.56^{* *}$ & $0.47^{* *}$ \\
\hline \multicolumn{4}{|c|}{ No. of living children } \\
\hline 0 (ref) & 1.00 & 1.00 & 1.00 \\
\hline $1-3$ & $1.72^{* *}$ & 0.96 & 1.34 \\
\hline$\geq 4$ & $4.80^{* *}$ & 0.89 & 0.84 \\
\hline \multicolumn{4}{|c|}{ No. of prior induced abortions } \\
\hline 0 (ref) & 1.00 & 1.00 & 1.00 \\
\hline 1 & $4.41^{* *}$ & 1.07 & $2.21^{* *}$ \\
\hline$\geq 2$ & $3.66^{* *}$ & $0.51^{* *}$ & $1.63^{* *}$ \\
\hline \multicolumn{4}{|l|}{ Wks. of gestation } \\
\hline$<8$ (ref) & 1.00 & 1.00 & 1.00 \\
\hline $8-12$ & $0.15^{* *}$ & $1.78^{* *}$ & $4.83^{* *}$ \\
\hline$\geq 13$ & $0.06^{* *}$ & $3.64^{* *}$ & $20.84^{* *}$ \\
\hline
\end{tabular}

${ }^{*} p<.05 .{ }^{* *} p<.01 .+p<.10 . \neq$ Respondent had at least some schooling at this level. Note: ref=reference group.

tion directly from the hospital, compared with $20 \%$ in the North. In the South, the proportion who went directly to the hospital to obtain an abortion was similar to the proportion who had attempted to end their pregnancy elsewhere, whereas in the North, women were more likely to have made an abortion attempt before coming to the hospital.
The four types of hospitals differed in the types of patients seen. More than $70 \%$ of the tertiary hospital patients were classified as having complications of spontaneous abortion. Sixty percent of the secondary hospital patients had an abortion, with 26\% being treated for complications of an abortion performed elsewhere, 10\% receiving a termination at the hospital after a failed attempt elsewhere and $24 \%$ having the procedure at the hospital without a prior attempt. The private hospitals primarily served women seeking to end their pregnancy (71\%); in the two mission hospitals, however, the great majority of interviewed women were treated for complications of either an induced abortion performed elsewhere $(80 \%)$ or a spontaneous abortion (17\%); very few women (3\%) sought an abortion at these sites.

\section{Characteristics of Patient Groups}

In bivariate analyses, women who had an induced abortion-whether induced in the hospital with no prior attempt, attempted with no serious complications before coming to the facility or attempted with serious complications-were younger and much less likely to be married than women being treated for a spontaneous abortion (Table 2, page 43). They were more likely to be Christian, and tended to have more education and a higher standard of living. They were also more likely than women with a spontaneous abortion to live in villages; this may indicate that rural women tended to travel farther for induced abortion services than for treatment of spontaneous abortion, or that rural women with complications of spontaneous abortion were less likely to obtain care. Women who had an induced abortion had fewer children and were more likely to have had a previous induced abortion than those who had a spontaneous abortion. Their abortion was also much more likely to have occurred during the first seven weeks of pregnancy.

There were also two notable differences among the three categories of women who had induced abortion (Table 2). Compared with women who came directly to the hospital to seek an abortion, the two groups of women who had attempted an abortion before coming to hospital tended to be poorer and later in gestation.

The results of a multivariate analysis comparing women who had a spontaneous abortion with those who had an induced abortion (Table 3) were generally similar to those in the bivariate analyses. However, there were some differences. Education and standard of living were no longer associated with induced abortion when other factors were controlled for. In addition, the odds of having an induced abortion rather than a spontaneous abortion were significantly higher among women with 1-3 children (odds ratio, 1.7) or four or more children (4.8) than among those with none.

Further multivariate analyses looked at differences among women who had induced abortions. The odds of having an induced abortion at the hospital after attempting to have an abortion elsewhere rather than going di- 
rectly to the hospital for the procedure were higher among women who were 25-29 rather than 19 or younger (odds ratio, 1.6). The odds of having or attempting to have an abortion elsewhere rather than going directly to the hospital were lower among women who were not poor than among those who were ( 0.5 and 0.6 ); the odds were higher among women who had an abortion after seven weeks of gestation than among those who had had an earlier termination (1.8-20.8).

Women with primary education were more likely than those with no schooling to have come to the hospital with serious complications from a prior attempt at termination rather than to have come directly to the hospital (odds ratio, 2.6). The odds were also higher among women living in the North than among those living in the South (1.7). In comparison with women who had had no prior induced abortions, those who had had two or more were less likely to have come to the hospital after an outside abortion attempt without serious complications than to have come directly to the hospital (0.5); however, such women were more likely to have come to the hospital with serious complications from an outside abortion than to have come directly to the hospital (1.6).

\section{Providers and Methods}

Thirty-five percent of women reported taking more than one step to obtain an abortion before coming to the hospital; on average, women took 1.5 steps (not shown). Twenty-nine percent consulted a physician at their first attempt to terminate the pregnancy. An additional 12\% first went to a provider with less training and then went to a physician either to treat complications or because the earlier attempt had not been successful.

Among all women who attempted an abortion before coming to the hospital, those in the North were much more likely than those in the South to have consulted a physician in at least one attempt (59\% vs. 25\%-Table 4). Overall, 35\% had consulted a chemist in at least one attempt. Smaller numbers of women had gone to a nurse or midwife (13\%); a friend, partner or relative $(10 \%)$; or a traditional healer (6\%).

The type of provider women saw for an abortion was associated with whether or not the abortion attempt resulted in a serious complication. Overall, women who experienced no serious complications were most likely to have seen a chemist for at least one of their abortion attempts (42\%), while women who had serious complications were most likely to have seen a physician (51\%). The situation in the South reflects this overall picture. In the North, however, the majority in both groups of women reported having seen a physician for at least one of their attempts (60\% and $59 \%$ respectively). It is not clear to what extent these data reflect difficulties women may have had in differentiating between physicians and other providers.

According to women who had attempted to terminate their pregnancy before coming to the hospital, pills and dilation and curettage (D\&C) were the most common meth-
TABLE 4. Among women who attempted to end their pregnancy before coming to the hospital and provided information about their attempts, percentage who ever saw specific provider types, by region

\begin{tabular}{|c|c|c|c|}
\hline Provider & Total & South & North \\
\hline \multicolumn{4}{|l|}{ All women who attempted an abortion } \\
\hline Physician & 40.2 & 24.8 & $59.1^{* *}$ \\
\hline Chemist & 35.1 & 35.2 & 34.9 \\
\hline Self & 14.2 & 16.4 & $11.5+$ \\
\hline Nurse/midwife & 12.5 & 13.6 & 11.2 \\
\hline Partner/friend/relative & 10.0 & 12.1 & $7.4 \dagger$ \\
\hline Native doctor/traditional healer & 5.7 & 6.4 & 4.8 \\
\hline Other/other health provider & 4.2 & 3.6 & 4.8 \\
\hline Did not specify & 8.3 & 9.4 & 7.1 \\
\hline \multicolumn{4}{|l|}{ Women who presented at hospital with no serious } \\
\hline Physician & 20.6 & 4.6 & $59.7^{* *}$ \\
\hline Chemist & 41.6 & 45.4 & $32.3 \dagger$ \\
\hline Self & 20.6 & 23.7 & $12.9+$ \\
\hline Nurse/midwife & 6.5 & 7.2 & 4.8 \\
\hline Partner/friend/relative & 14.5 & 16.4 & 9.7 \\
\hline Native doctor/traditional healer & 3.7 & 4.6 & 1.6 \\
\hline Other/other health provider & 1.9 & 2.6 & 0.0 \\
\hline Did not specify & 8.9 & 8.6 & 9.7 \\
\hline \multicolumn{4}{|l|}{ Women who presented with serious complications } \\
\hline Physician & 51.2 & 42.1 & $58.9^{* *}$ \\
\hline Chemist & 31.4 & 26.4 & $35.7^{*}$ \\
\hline Self & 10.6 & 10.1 & 11.1 \\
\hline Nurse/midwife & 15.8 & 19.1 & 13.0 \\
\hline Partner/friend/relative & 7.5 & 8.4 & 6.8 \\
\hline Native doctor/traditional healer & 6.8 & 7.9 & 5.8 \\
\hline Other/other health provider & 5.5 & 4.5 & 6.3 \\
\hline Did not specify & 8.1 & 10.1 & 6.3 \\
\hline
\end{tabular}

${ }^{*} \mathrm{p}<.05 .{ }^{*} \mathrm{p}<.01 .+\mathrm{p}<.10$. Notes: Percentages add to more than $100 \%$ because women could go to several sources. Significance testing compares the distribution of women who went to a specific provider type by region of residence to the distribution of women who did not go to the provider type. ref=reference group.

TABLE 5. Percentage distribution of steps taken by women who had attempted to end their pregnancy before coming to the hospital, by type of method, according to type of provider

Method Provider

\begin{tabular}{|c|c|c|c|c|c|c|c|c|}
\hline & $\begin{array}{l}\text { Total } \\
(\mathrm{N}=875) \neq\end{array}$ & $\begin{array}{l}\text { Doctor } \\
(\mathrm{N}=292)\end{array}$ & $\begin{array}{l}\text { Chemist } \\
(\mathrm{N}=232)\end{array}$ & $\begin{array}{l}\text { Self } \\
(N=92)\end{array}$ & $\begin{array}{l}\text { Nurse/ } \\
\text { midwife } \\
\text { (N=81) }\end{array}$ & $\begin{array}{l}\text { Friend/ } \\
\text { e partner/ } \\
\text { relative } \\
(\mathrm{N}=65)\end{array}$ & $\begin{array}{l}\text { Native } \\
\text { doctor/ } \\
\text { traditional } \\
\text { healer } \\
(\mathrm{N}=36)\end{array}$ & $\begin{array}{l}\text { Other } \\
(\mathrm{N}=19)\end{array}$ \\
\hline Pills & 26.3 & 3.8 & 55.6 & 52.2 & 11.1 & 47.7 & 0.0 & 10.5 \\
\hline $\begin{array}{c}\text { Dilation and } \\
\text { curettage }\end{array}$ & 29.1 & 54.8 & 5.1 & 4.3 & 43.2 & 7.7 & 2.8 & 42.1 \\
\hline Injection & 16.0 & 7.5 & 32.3 & 6.5 & 21.0 & 6.2 & 0.0 & 10.5 \\
\hline $\begin{array}{l}\text { Manual vacuum } \\
\text { aspiration }\end{array}$ & 8.9 & 19.5 & 0.9 & 1.1 & 19.8 & 0.0 & 2.8 & 5.3 \\
\hline $\begin{array}{l}\text { Native medicine, } \\
\text { herbs }\end{array}$ & & & & & & & & \\
\hline $\begin{array}{l}\text { herbs } \\
\text { Inserted object }\end{array}$ & $\begin{array}{l}5.5 \\
5.6\end{array}$ & $\begin{array}{l}0.0 \\
6.2\end{array}$ & $\begin{array}{l}0.4 \\
3.0\end{array}$ & $\begin{array}{r}16.3 \\
4.3\end{array}$ & $\begin{array}{l}2.5 \\
0.0\end{array}$ & $\begin{array}{r}13.8 \\
6.2\end{array}$ & $\begin{array}{l}55.6 \\
36.1\end{array}$ & $\begin{array}{l}0.0 \\
0.0\end{array}$ \\
\hline Other§ & 6.7 & 6.8 & 1.7 & 15.2 & 1.2 & 15.4 & 0.0 & 31.6 \\
\hline $\begin{array}{l}\text { Did not specify/ } \\
\text { did not know }\end{array}$ & 1.8 & 1.4 & 0.9 & 0.0 & 1.2 & 3.1 & 2.8 & 0.0 \\
\hline Total & 100.0 & 100.0 & 100.0 & 100.0 & 100.0 & 100.0 & 100.0 & 100.0 \\
\hline $\begin{array}{l}\text { Mean amount } \\
\text { paid by patient } \\
\text { (naira) }\end{array}$ & 2,189 & 5,538 & 624 & 277 & 2,066 & 309 & 1,260 & 1,690 \\
\hline $\begin{array}{l}\text { Mean days spent } \\
\text { in hospital }\end{array}$ & 1.7 & 2.5 & 1.5 & 1.4 & 2.4 & 1.4 & 1.9 & 2.7 \\
\hline
\end{tabular}

$\neq \mathrm{N}=$ number of steps women reported in the process of seeking an abortion before arriving in the hospital. $\mathrm{A}$ provider was not specified for 58 steps taken. §Other methods include drinking alcohol, massage and lifting heavy objects. Note: Distributions may not add to 100.0 because of rounding. 
TABLE 6. Among women who made prior attempts to end their pregnancy, percentage with self-reported complications or symptoms reported by doctor on admission to hospital, according to abortion method

Complication Method at last attempt

All D\&C Pills Injection MVA Inserted Herbs, native Otherł
$(\mathrm{N}=586) \quad(\mathrm{N}=221) \quad(\mathrm{N}=144) \quad(\mathrm{N}=76) \quad(\mathrm{N}=51) \quad$ object $\quad$ medicine $\quad(\mathrm{N}=27)$ $(\mathrm{N}=42) \quad(\mathrm{N}=24)$

\begin{tabular}{|c|c|c|c|c|c|c|c|c|}
\hline \multicolumn{9}{|c|}{ Self-reported serious complication§ } \\
\hline Pain & 51.5 & 68.3 & 22.9 & 40.8 & 60.8 & 71.4 & 50.0 & 48.1 \\
\hline Bleeding & 43.6 & 59.3 & 19.4 & 26.3 & 62.7 & 59.5 & 37.5 & 37.0 \\
\hline Fever & 13.8 & 19.0 & 5.6 & 7.9 & 7.8 & 28.6 & 12.5 & 22.2 \\
\hline Injuries & 7.9 & 12.6 & 1.4 & 1.3 & 9.8 & 11.9 & 8.3 & 3.7 \\
\hline Other & 2.6 & 3.6 & 1.4 & 2.6 & 0.0 & 2.4 & 4.2 & 3.7 \\
\hline Minor only & 37.8 & 20.4 & 66.0 & 52.6 & 19.6 & 19.0 & 41.7 & 11.1 \\
\hline \multicolumn{9}{|c|}{ Symptom reported by doctor on admission } \\
\hline Pain & 55.8 & 71.9 & 31.3 & 40.3 & 90.2 & 59.5 & 33.3 & 48.1 \\
\hline \multicolumn{9}{|l|}{$\begin{array}{l}\text { Bleeding/ } \\
\text { retained }\end{array}$} \\
\hline products & 54.8 & 73.8 & 27.8 & 33.8 & 94.1 & 57.1 & 29.2 & 48.1 \\
\hline Fever & 17.1 & 26.2 & 6.3 & 7.8 & 17.6 & 26.2 & 8.3 & 18.5 \\
\hline \multicolumn{9}{|l|}{$\begin{array}{l}\text { Genital/ } \\
\text { cervical }\end{array}$} \\
\hline trauma & 11.8 & 20.8 & 2.1 & 2.6 & 9.8 & 14.3 & 4.2 & 22.2 \\
\hline None & 36.3 & 17.2 & 62.5 & 58.4 & 5.9 & 31.0 & 58.3 & 37.0 \\
\hline
\end{tabular}

‡Other methods include drinking alcohol, massage and lifting heavy objects. §Following last abortion attempt. Note: Women and doctors could report more than one serious complication or presenting symptom.

TABLE 7. Percentage of women treated at hospital, by diagnosis, treatment and length of stay, according to type of abortion

\begin{tabular}{|c|c|c|c|c|}
\hline \multirow{2}{*}{$\begin{array}{l}\text { Diagnosis, treatment } \\
\text { and stay }\end{array}$} & \multirow{2}{*}{$\begin{array}{l}\text { Spontaneous } \\
(\mathrm{N}=666)\end{array}$} & \multicolumn{3}{|l|}{ Induced } \\
\hline & & $\begin{array}{l}\text { Obtained } \\
\text { outside hospital } \\
\text { with serious } \\
\text { presenting } \\
\text { serious } \\
\text { complications } \\
(\mathrm{N}=491)\end{array}$ & $\begin{array}{l}\text { Induced in } \\
\text { hospital } \\
\text { after outside } \\
\text { attempt with } \\
\text { no serious } \\
\text { presenting } \\
\text { complications } \\
(\mathrm{N}=254)\end{array}$ & $\begin{array}{l}\text { Induced in } \\
\text { hospital; } \\
\text { no prior } \\
\text { outside } \\
\text { attempt } \\
(\mathrm{N}=682)\end{array}$ \\
\hline \multicolumn{5}{|l|}{ Discharge diagnosis } \\
\hline $\begin{array}{l}\text { Retained products } \\
\text { of conception }\end{array}$ & 52.1 & 50.3 & 28 & 03 \\
\hline Hemorrhage & 23.4 & 33.6 & 1.6 & 0.7 \\
\hline Fever & 6.0 & 34.4 & 2.4 & 0.3 \\
\hline Sepsis & 2.1 & 23.5 & 1.2 & 0.3 \\
\hline Pelvic infection & 1.8 & 21.4 & 1.2 & 0.3 \\
\hline Instrumental injury & 0.3 & 11.4 & 0.0 & 0.3 \\
\hline Shock & 1.2 & 4.3 & 0.0 & 0.0 \\
\hline Death & 0.2 & 2.4 & 0.4 & 0.0 \\
\hline \multicolumn{5}{|l|}{ Treatment } \\
\hline Uterine evacuation & 93.7 & 80.4 & 98.4 & 98.1 \\
\hline MVA & 77.0 & 55.6 & 65.4 & 66.9 \\
\hline$D \& C / D \& E$ & 8.9 & 17.9 & 26.8 & 29.5 \\
\hline Labor induction & 8.0 & 6.9 & 6.3 & 1.8 \\
\hline Abdominal surgery & 0.3 & 9.6 & 0.0 & 0.0 \\
\hline Blood transfusion & 5.4 & 21.6 & 1.6 & 0.0 \\
\hline IV antibiotics & 20.9 & 47.5 & 11.0 & 7.0 \\
\hline \multicolumn{5}{|l|}{ No. of nights in hospital } \\
\hline Outpatient & 52.7 & 33.6 & 90.5 & 96.2 \\
\hline 1 & 20.1 & 23.5 & 1.2 & 1.9 \\
\hline 2 & 11.3 & 15.1 & 2.0 & 0.7 \\
\hline $3-4$ & 9.7 & 12.4 & 5.6 & 1.2 \\
\hline $5-9$ & 4.9 & 9.5 & 0.4 & 0.0 \\
\hline$\geq 10$ & 1.4 & 5.9 & 0.4 & 0.0 \\
\hline Mean no. of days in hospital & 1.0 & 2.5 & 0.3 & 0.1 \\
\hline
\end{tabular}

ods used by the abortion providers they saw, followed by injections and manual vacuum aspiration (MVA) (Table 5). Physicians most often performed a D\&C (55\%) or an MVA (20\%), while chemists usually provided pills (56\%) or injections (32\%). There is no information on exactly what the pills or injections were. While some women may have received misoprostol, the drug was not widely available in Nigeria at the time of the study. Abortion attempts the women made themselves or with assistance from friends usually involved pills or traditional medicines or herbs. Nurses and midwives most often used D\&C (43\%), followed by injections (21\%), MVA (20\%) and pills (11\%). Traditional healers most often used herbs or other traditional medicines (56\%) or inserted objects (36\%).

\section{Complications Among Women Who Attempted Abortion}

As Table 6 shows, the most common serious complications reported by women admitted to the hospital after an abortion attempt were pain (52\%) and bleeding (44\%). Fourteen percent reported fever, and smaller proportions reported injuries and other complications. Thirty-eight percent reported minor complications.

The results of the hospital physicians' examination were similar to the women's reports of complications. When there were differences, the incidence of a complication reported by the physicians was generally higher-for example, bleeding (55\% vs. 44\%, respectively) and genital or cervical trauma or injuries ( $12 \%$ vs. $8 \%$ ). According to both women's self-reporting and physicians' reports at admission, women's symptoms varied greatly according to the method used to end the pregnancy. A majority of women who had a D\&C or an MVA experienced bleeding and pain. A substantial proportion also had fever or genital or cervical trauma on admission. According to physicians' reports, these two symptoms were more common among women who had had a D\&C (26\% and 21\%) than among those who had had an MVA (18\% and 10\%).

Physicians' reports indicated that $58-63 \%$ of women who took pills, injections or traditional medicines had no symptoms on admission. However, $28-40 \%$ of these women arrived at the hospital with bleeding, pain or retained products of conception. Fever and injury were relatively rare (2-8\%).

Physicians found no symptoms in 31\% of women who said they had inserted objects, suggesting that the objects might not have reached the cervix. However, the majority arrived with pain and bleeding, 26\% with fever and 14\% with cervical or genital trauma.

Bleeding and pain were most common among women who had had a D\&C or an MVA, procedures most often performed by doctors. Thus, these symptoms were most frequently found in women who had sought pregnancy termination from a doctor (not shown). The doctor was sometimes the last person seen, so in some cases these complications may have been caused by the doctor; however, earlier abortion attempts may also have been the cause of the complications. 


\section{Medical Diagnosis and Treatment}

Table 7 compares the medical diagnosis and the medical care received in the four patient groups. Two groupsthose who had complications from a prior abortion attempt at the time they were admitted and those who had had a spontaneous abortion-had high proportions of women with retained products of conception and hemorrhage. Among women whose attempt to induce an abortion outside the hospital had resulted in complications, $34 \%$ had fever, $24 \%$ sepsis and $21 \%$ pelvic infection; $11 \%$ had been injured by the instruments used in the abortion attempt, and $4 \%$ were in shock. Some $2.4 \%$ of this group died from their complications. * Of the 12 women in this study who died after a prior abortion attempt, seven were in the second trimester of pregnancy. In comparison, one death occurred among women who had had a spontaneous abortion, for a mortality rate of $0.1 \%$.

Few complications were reported in the other two groups of abortion patients-those who attempted to induce the abortion before coming to the hospital but had no evident symptoms, and those who requested and obtained an abortion at the hospital. Only $2-3 \%$ of the former group had fever, hemorrhage or retained products of conception; levels of all other complications were $1 \%$ or less for both groups of patients.

At the hospital, most patients received a uterine evacuation, usually by MVA, which is considered the safest method for first-trimester pregnancies. Treatments other than uterine evacuation were rarely required for the women without symptoms, but were necessary for a substantial proportion of women who had complications of induced abortion and for a small proportion of women who had had a spontaneous abortion. Twenty-two percent of women treated for induced abortion complications had blood transfusions and $10 \%$ had abdominal surgery, compared with 5\% and 0.3\% for women treated for spontaneous abortion. Two-thirds of the women with abortion complications stayed in the hospital for at least one night, and 6\% stayed for 10 or more nights. Only about half of the patients with a spontaneous abortion stayed overnight, and women who came directly to the hospital for an abortion rarely did so (4\%).

\section{Cost of Treatment to Women}

We calculated the cost of treatment for three groups of women: those who had attempted to induce abortion and came to the hospital with complications; a group combining (because of their lack of complications at admission) women who had attempted an abortion before coming to the hospital but had no serious complications and those who came directly to the hospital to seek a termination; and women who had had a spontaneous abortion (Table 8). The greatest expense, averaging nearly 11,000 naira per patient, was for women treated for serious complications of abortion attempts outside the hospital. ${ }^{\dagger}$ This total included about 7,900 naira for the hospital, which usually included physician care, 1,200 naira for supplies and 1,900 naira for medications. In addition, before going to

\begin{abstract}
TABLE 8. Mean amount paid (in Nigerian naira) for abortion and treatment of complications, by type of expense, and factors affecting actual amount women paid, according to type of abortion
\end{abstract}

\begin{tabular}{|c|c|c|c|}
\hline \multirow[t]{2}{*}{ Type of expense } & \multicolumn{2}{|l|}{ Induced } & \multirow{2}{*}{$\begin{array}{l}\text { Spontaneous } \\
(\mathrm{N}=604)\end{array}$} \\
\hline & $\begin{array}{l}\text { Obtained } \\
\text { outside hospital, } \\
\text { with serious } \\
\text { presenting } \\
\text { complications } \\
(\mathrm{N}=470)\end{array}$ & $\begin{array}{l}\text { Induced in } \\
\text { hospital } \neq \\
(\mathrm{N}=878)\end{array}$ & \\
\hline \multicolumn{4}{|l|}{ MEAN AMOUNT PAID§ } \\
\hline Charges in hospital & 10,971 & 3,605 & 5,114 \\
\hline Hospital & 7,846 & 3,267 & 3,957 \\
\hline Doctors & 81 & 97 & 25 \\
\hline Supplies & 1,162 & 77 & 336 \\
\hline Medications & 1,884 & 165 & 795 \\
\hline \multicolumn{4}{|l|}{$\begin{array}{l}\text { Amount paid for } \\
\text { abortion attempt } \\
\text { before going to }\end{array}$} \\
\hline Total & 13,865 & 3,844 & 5,114 \\
\hline \multicolumn{4}{|c|}{$\begin{array}{l}\text { FACTORS AFFECTING ACTUAL AMOUNT PAID } \\
\text { Gestation }\end{array}$} \\
\hline$<12$ wks. & 10,884 & 3,302 & 4,272 \\
\hline$\geq 13$ wks. & 10,964 & 9,508 & 7,048 \\
\hline \multicolumn{4}{|c|}{ Severity of complicationst† } \\
\hline Severe & 11,829 & na & 6,920 \\
\hline Less severe & 8,744 & na & 3,696 \\
\hline \multicolumn{4}{|l|}{ Treatment in hospital } \\
\hline MVA & na & 3,446 & na \\
\hline $\mathrm{D} \& \mathrm{C}$ & na & 3,090 & na \\
\hline
\end{tabular}

\#Includes both women who attempted an abortion outside the hospital but had no serious complications, and those who sought an induced abortion at the facility. §Data on hospital charges came from physician interviews; information on costs of prior attempts came from patient interviews. Costs associated with complications experienced after interview in hospital are not included in the total because they could not be determined. $\dagger+$ Severe complications include sepsis, shock, pelvic infection, injury, fever or death. Less severe complications include hemorrhage or having retained products of conception.

the hospital, these women had paid an average of about 2,900 naira for the abortion attempts that caused the complications. In all, pregnancy termination and treatment cost about 13,900 naira for this group. Women needing treatment of spontaneous abortion paid less than half this amount-5,100 naira, on average.

Least expensive was abortion provided in the hospital for women who had made no prior attempts and those whose prior attempts had not resulted in serious complications (3,800 naira). The average cost of prior abortion attempts for women who ultimately received an abortion in the hospital and who had a prior failed attempt but did not have any symptoms, was 1,100 naira (not shown); when averaged over all women in this combined group, the average per woman was 239 naira (Table 8).

\footnotetext{
*This percentage may underestimate mortality from unsafe abortion in Nigeria because some women who were very sick when admitted to the hospital may have died before they could be interviewed, and some
} women are likely to have died before reaching a hospital.

†One U.S. dollar was about 120 naira at the time of this survey. 
In addition, for the group of patients who attempted to induce an abortion before coming to the hospital and who had complications, we examined the relationship between severity of complications and cost of medical care in the hospital. We explored two measures of severity-having an abortion within the first 12 weeks of pregnancy versus having an abortion at 13 or more weeks of gestation (because of the expected strong association between later gestation and adverse health consequences), and having retained products of conception or hemorrhage (less severe) versus having at least one more serious complication (more severe). Hospital care associated with abortion in the second trimester was much more costly than care associated with earlier abortions, although this was not the case for women who had serious complications from abortion attempts before coming to the hospital. In addition, the average cost of medical care for women who suffered severe health consequences from abortion attempts is about 35\% higher than that for women with less severe complications (11,800 compared to 8,700 naira).

The cost of using MVA to perform an abortion was slightly higher than the cost of using D\&C (3,446 vs. 3,090 naira), an unexpected result. Because MVA is a relatively new technology, Nigerian providers may not yet have factored this lower cost into the amount they charge clients or they may be charging for single-use MVA kits. The instruments used for D\&C procedures, on the other hand, last for a long time, resulting in lower costs for individual women.

For women with complications of abortion attempts, the costs in private hospitals (5,000 naira) were lower than in other types of hospitals (10,300-16,200 naira; data not shown): it is likely that public and mission hospitals were more costly because they receive patients with more severe complications and provide more comprehensive care. Charges for abortions induced in the hospital were similar in secondary and private hospitals (3,500 naira), but much higher in tertiary hospitals (12,500 naira; not shown), where such procedures make up a much smaller proportion of the caseload (2.2\%; Table 1) and may be unusual in some way.

\section{DISCUSSION}

As this and other studies have shown, induced abortion is common in Nigeria despite the country's restrictive law, and it is very frequently unsafe. New research findings on women hospitalized for treatment of abortion complications, presented here, show that unsafe abortions exact a substantial cost in impaired health of women and in medical treatment expenses. Among women admitted with serious abortion complications, more than one-fifth had hemorrhage that required blood transfusion, about the same proportion had sepsis, 10\% required abdominal surgery and more than $2 \%$ died. This mortality rate indicates that, at a minimum, about 3,000 women in Nigeria die from unsafe abortion each year if the estimate of 142,000 women treated annually for complications calculated in an earlier study is accurate; however, since many die before reaching a facility, the true number of women dying from abortionrelated complications is likely to be much higher than this. In this study, the financial cost to the women and their families of treating complications resulting from unsafe abortion was almost four times the cost of a safe abortion provided in the hospital.

The large number of women who came to the hospital with complications after having been treated by a physician indicates that many doctors are not well-trained in abortion services and postabortion care. The problem may be greatest in the North, which had the largest proportion of complications caused by physicians. It is not always clear whether the doctors were fully trained physicians or were less-trained persons who called themselves, or whom women considered to be, doctors. However, many probably had formal medical training, given that they frequently used D\&C and MVA. A companion survey to this study found that among a household sample of women of reproductive age, $25 \%$ of those who went to a private hospital or clinic for an abortion said that they had had complications that required treatment. ${ }^{5}$

Unsafe abortion absorbs household and health care resources and creates a major problem in both the more developed and more traditional areas of Nigeria. The current study has no information on the proportion of the total cost of postabortion care that is borne by women and their family rather than the health care system. However, evidence from a recent attempt to estimate the costs of providing hospital-based postabortion care to Nigerian women who need it, using a variant of the Mother-BabyPackage (MBP) developed by the World Health Organization, showed that on average, it will cost a total of $\$ 132$ per woman to provide these services. ${ }^{4}$ Out of this total amount, on average, $\$ 95$ (71\%) will be charged to the woman and her family; the health care system will assume the remaining $\$ 37$.

With recent data indicating that more than one-quarter ( $27 \%$ ) of Nigerian women have an unmet need for effective methods of contraception, ${ }^{12}$ the risk of unwanted pregnancy-and unsafe abortion-is already high. The prevalence of abortion is higher in the more developed South than in the more rural North, which suggests that the problem will increase as economic development progresses, unless appropriate measures are taken to prevent it. ${ }^{13}$ With increasing education and affluence, women in the North are also likely to want smaller families, and to delay getting married, and unless other factors change (for example, if effective contraceptive use increases or access to safe abortion increases), unmet need for contraception will rise and the risk of unwanted pregnancy and unsafe abortion will also increase.

There is no indication that these problems will diminish without active policy and programmatic intervention. Our results suggest several potential approaches to the problems associated with unsafe abortion. For example, widespread training for doctors in abortion procedures 
would lower rates of complications and serious injuries among women seeking treatment after unsafe abortions and make it possible to provide safe abortion services for women who meet the existing criteria for legal abortions. Such interventions, however, would have limited impact absent a change in abortion laws, which permit abortion only to save a woman's life.

Other approaches, however, can be taken to reduce unsafe abortion and its consequences. First, the number of unwanted pregnancies can be reduced by disseminating accurate information about contraception, providing and subsidizing a full range of contraceptive services and supplies, and offering counseling to aid couples in choosing methods that are appropriate for them and in using them correctly and consistently. Second, when women do resort to illegal abortion-as they frequently do-to end an unwanted pregnancy, the number who die or suffer longlasting health problems can be decreased by providing hospitals and clinics with efficient and cost-effective postabortion care technology, such as MVA equipment, at low cost, training physicians in its operation and maintenance and training nurses to provide contraceptive counseling after treatment. Although these two approaches alone cannot end the problems resulting from unsafe abortion, their widespread adoption would do a great deal to reduce their incidence and their human and monetary costs.

\section{REFERENCES}

1. Henshaw SK et al., The incidence of induced abortion in Nigeria, International Family Planning Perspectives, 1998, 24(4):156-164.

2. World Health Organization (WHO), Unsafe Abortion: Global and Regional Estimates of the Incidence of Unsafe Abortion and Associated Mortality in 2000, fourth ed., Geneva: WHO, 2004.

3. Oye-Adeniran B, Umoh AV and Nnatu SN, Complications of unsafe abortion: a case study and the need for abortion law reform in Nigeria, Reproductive Health Matters, 2002, 10(19):18-21.

4. Bankole A et al., Estimating the cost of post-abortion care in Nigeria: a case study, in Lule E, Singh S and Chowdhury SA, eds., Fertility Regulation Behaviors and Their Costs: Contraception and Unintended Pregnancies in Africa and Eastern Europe \& Central Asia, Washington, DC: World Bank, 2007.

5. Bankole A et al., Abortion seeking behavior among Nigerian women, Journal of Biosocial Science, 2008, 40(2):247-268.

6. Makinwa-Adebusoye P, Singh S and Audam S, Nigerian health professionals' perceptions about abortion practice, International Family Planning Perspectives, 1997, 23(4):155-161.

7. Federal Office of Statistics and IRD/Macro International, Nigeria Demographic and Health Survey 1990, Columbia, MD, USA: IRD/Macro International, 1992.

8. National Population Commission (NPC), Federal Republic of Nigeria and ORC Macro, Nigeria Demographic and Health Survey 2003, Calverton, MD, USA: NPC and ORC Macro, 2004.

9. Alan Guttmacher Institute (AGI), Into a New World, New York: AGI, 1998.

10. AGI, Early childbearing in Nigeria: a continuing challenge, Research in Brief, New York: AGI, 2004.

11. Guttmacher Institute, unpublished tabulation of the 1990 and 2003 Nigeria Demographic and Health Surveys, New York: Guttmacher Institute, 2006.

12. AGI, Reducing unintended pregnancy in Nigeria: differing contraceptive needs, Research in Brief, New York: AGI, 2005.
13. Sedgh $G$ et al., Unwanted pregnancy and associated factors among Nigerian women, International Family Planning Perspectives, 2006, 32(4):175-184.

\section{RESUMEN}

Contexto: Cada año, miles de mujeres nigerianas tienen embarazos no planeados que terminan en abortos ilegales. Muchos de esos procedimientos ocurren bajo condiciones inseguras, lo que contribuye a la morbilidad y mortalidad maternas. Métodos: En una encuesta aplicada en 2002-2003 a mujeres y sus proveedores de servicios en 33 hospitales, en ocho estados en Nigeria, se identificó a 2,093 pacientes que estaban recibiendo tratamiento para complicaciones de aborto inducido o espontáneo, o que solicitaban un aborto en el hospital. Las experiencias de aborto de las mujeres, así como las consecuencias para su salud y los costos asociados, se examinaron a través de análisis bivariado. Se utilizó análisis multivariado para examinar las características de las mujeres por tipo de pérdida del embarazo y para comparar las características entre las tres grupos de mujeres que habian tenido un aborto inducido-las que acudieron al hospital con aborto incompleto no complicado; las que habian desarrollado complicaciones postaborto; y las que solicitaban y recibieron un aborto en el hospital.

Resultados: Entre las mujeres que fueron atendidas por razones relacionadas con pérdidas de embarazo, 36\% habian intentado terminar el embarazo antes de llegar al hospital (incluyendo 24\% con serias complicaciones y $12 \%$ sin ellas); $33 \%$ obtuvieron un aborto inducido en la institución (a pesar de la ley restrictiva del país) sin un intento previo de aborto; y 32\% recibieron tratamiento para complicaciones debido a un aborto espontáneo. De las mujeres que habian desarrollado complicaciones postaborto, 24\% tenían septicemia, 21\% infección pélvica y $11 \%$ daño causado por instrumentos; $22 \%$ requirieron una transfusión de sangre y 10\% necesitaron cirugía abdominal. Las mujeres en este grupo eran más pobres y tenían una gestación más avanzada que las que buscaron un aborto directamente en el hospital. Las mujeres con complicaciones pagaron más por su aborto y tratamiento (cerca de 13,900 naira) que quienes acudieron directamente al hospital para recibir un aborto (3,800 naira) o quienes recibieron tratamiento por aborto espontáneo (5,100 naira).

Conclusiones: Se necesita intervenciones de políticas y de programas para mejorar el acceso a los servicios anticonceptivos y la atención postaborto, con el fin de reducir la morbilidad y la mortalidad relacionadas con el aborto.

\section{RÉSUMÉ}

Contexte: Chaque année, des milliers de Nigérianes font l'expérience de grossesses non planifiées qu'elles interrompent illégalement. Les conditions rarement médicalisées de ces avortements clandestins contribuent à la morbidité et à la mortalité maternelles.

Méthodes: Une enquête menée en 2002-2003 auprès de femmes et de leurs prestataires dans 33 hôpitaux de huit états du Nigeria a identifié 2.093 patientes comme étant traitées pour complications d'IVG, avortement spontané ou demande d'avortement. Les expériences de l'avortement des femmes et 
les conséquences médicales et coûts associés ont été examinés par analyse bivariée. Les caractéristiques des femmes par type d'interruption de grossesse et celles de trois groupes de femmes avortées dans des circonstances distinctes ont été examinées et comparées, respectivement, par analyse multivariée.

Résultats: Des femmes admises pour raisons liées à l'avortement, 36\% avaient tenté d'interrompre leur grossesse avant de se rendre à l'hôpital (24\% avec et $12 \%$ sans complications graves), $33 \%$ avaient obtenu un avortement (malgré la legislation restrictive du pays) à l'établissement même sans avoir d'abord tenté d'IVG et 32\% étaient traitées pour complications d'avortement spontané. De celles atteintes de complications graves, $24 \%$ souffraient de septicémie, $21 \%$ avaient une infection pelvienne et $11 \%$ présentaient une blessure causée par un instrument; $22 \%$ avaient requis une transfusion sanguine et $10 \%$, une intervention chirurgicale abdominale. Les femmes de ce groupe étaient plus pauvres et avaient atteint un niveau de gestation plus avancé que celles qui s'étaient fait avorter directement à l'hôpital. Elles avaient payé plus pour leur traitement (environ 13.900 nairas) que celles qui s'étaient adressées directement à l'hôpital (3.800 nairas) ou qui yétaient traitées pour Un Avortement Spontané (5.100 Nairas).

Conclusions: Des interventions politiques et programmatiques sont nécessaires à un meilleur accès aux services de contraception et soins après avortement si l'on veut réduire les morbidité et mortalité liées à l'avortement.

\section{Acknowledgments}

This research was supported by grants from the John D. and Catherine T. MacArthur Foundation and the Packard Foundation.

Author contact:shenshaw@guttmacher.org

\section{Acknowledgment to Reviewers}

The editors wish to express their appreciation to the following reviewers for their assistance in evaluating material for International Family Planning Perspectives in 2007:

Tanya Abramsky
Sohail Agha
Deborah L. Billings
Ann K. Blanc
Sarah A. Burgard
Jacquelyn C. Campbell
Marion Carter
John B. Casterline
Minja Kim Choe
John G. Cleland
Deborah S. DeGraff
Laurie F. DeRose

Tanya Abramsky

Sohail Agha

Deborah L. Billings

Alan Flisher

James R. Foreit

Dirgha Ghimire

Mary Goodwin

Terence H. Hull

Shegs S. James

Barbara Janowitz

Shireen J. Jejeebhoy

J. Timothy Johnson

Kathleen Kurz

Yongfeng Liu

Kathleen Malley-Morrison

Rupsa Mallik
Cicely Marston
Eleanor Maticka-Tyndale
Karen McDonnell
Liesbeth Meuwissen
Diane M. Morrison
Sabu Padmadas
William Pan
Xiaohui Peng
Audrey Pettifor
John M. Pile
Saumya RamaRao

Khama Rogo

Naomi Rutenberg

Florina Serbanescu

Vinit Sharma

Phyllis W. Sharps

Ilene S. Speizer

Tara M. Sullivan

Katherine Trent

Sayeed Unisa

Jennifer A. Wagman

A.J. Francis Zavier

Elmer Zelaya

Zhenzhen Zheng 